\title{
Financing Small Scale Oil Palm Producers in the Western Region of Ghana-Ahanta West District
}

\author{
Martha Coleman (Corresponding author) \\ School of Business Studies, Takoradi Polytechni, Ghana \\ Tel: 233-244-692-994Ｅ-mail: naadjoacole@yahoo.com \\ Daniel Odei Okyere \\ School of Business Studies, Takoradi Polytechni, Ghana \\ Tel: 233-266-295-219Ｅ-mail: danookyere@yahoo.com
}

Received: January 1, 2016 Accepted: January 17, 2016

doi:10.5296/ber.v6i1.8808 URL: http://dx.doi.org/10.5296/ber.v6i1.8808

\begin{abstract}
Business finance has been a major problem facing most businesses, both the small and large companies as well as the medium ones. Small and Medium Scale Enterprises (SMEs) are no exceptions of the problems faced by businesses. These enterprises are mostly managed by low income earners. Some of these enterprises cannot grow into large companies because of lack of funds. The objectives of the study are to identify the various forms of funds available to SMEs in the oil palm producing sector of the Ahanta West District of the Western Region of Ghana, find out the funds that have been actually accessed by oil palm producers in the Ahanta West District, and identify some other means of financing the oil palm production. The study revealed that majority of oil palm producers in the Ahanta West District finance their operation with personal savings and have not accessed any loan from the banks.
\end{abstract}

Keywords: Financing, Ghana, Small Scale, Oil Palm Producers

\section{Introduction}

Small and Medium Enterprises (SMEs) play a significant role in the world's economy in both developed and developing countries. SMEs contribute a significant percentage of national income and employ a significant number of people in many countries around the world. SMEs are vital for economic growth and development because they encourage 
entrepreneurship, generate employment, and reduce poverty, which the oil palm producing sector is not an exception. According to Aryeetey (1998), in addition to contributing to Ghana's GDP, SMEs form a characteristic feature of the production landscape and provide about $85 \%$ of manufacturing employment. They play a crucial role in stimulating growth and reducing poverty. While recognizing the potential roles of SMEs, the ability of SMEs in playing these key roles depends largely on how they perform in the business environment. It is imperative to investigate the factors that propel the growth of such ventures. Performance of businesses is one key factor influencing their growth.

The SMEs like all other business entities depend heavily on financing, but sadly, they did not get such support to enable them to expand and move the wheels of development forward. SMEs, which are predominantly family owned, have unattractive credit and financial history. Only a few small scale enterprises are able to approach banks for start-up capital and others turn to banks for assistance for operational capital. They blame commercial banks for over concentrating on the huge corporate clients to the detriment of the SME's.

According to Ghana News Agency, Business and Finance on November 25, 2003, Professor Stephen Adei said that SMEs properly oriented were not as high-risk borrowers as they were perceived to be. "In Ghana, $80 \%$ of those who took loans under the Programme of Action to Mitigate the Social Cost of Adjustment (PAMSCAD) in the previous regime repaid it." The efforts of Emprendedores and Tecnologia (EMPRETEC), transferring managerial and training skills to SME's have shown that SME's grow very fast and needed to be considered as sources of bankable projects with very high futuristic potential. EMPRETEC has achieved 90\% recovery rate of its United Nations Development Programme (UNDP) grant credit facility, adding that, between 1987 and September 2003, the loan portfolio rose from 1.7 billion cedis to 8.2 billion cedis with beneficiaries increasing from 382 to 1213 .

A win-win situation where innovative approaches, such as replacing high-value collaterals with assets of businesses third-party personal guarantees instead of immovable assets of collaterals demanded by traditional bank. There are factors (internal and external) that enhance SME's competitiveness as well as affecting the financing of SME's especially those in the palm oil producing sector. These factors have both positive and negative effect on the business of these SME's, thereby, affecting the profitability and survival of these businesses.

\subsection{Statement of Problem}

Oil palm production has been the main occupation for the people of Ahanta West District in the Western Region of Ghana. They derive their livelihood from this oil palm production. People in the Western Region purchase this product purposely for the preparation of family meal as well as serving as one of the ingredients for the preparation of some traditional medicines and some exported to the neighboring countries. Other businesses such as the soap producers also depend on it as input or raw material. Junior and senior high schools in the Western Region also depend on the oil palm for preparation of the students' meal.

Increase in demand for their product, puts pressure on the limited quantities produced by them. Oil palm producers cannot increase their output due to lack of funds to purchase the 
palm fruits from the palm fruits producers. Due to that, the palm fruits producers tend to sell their produce to Norpalm Ghana Limited and Benso Oil Palm Company Limited, which pay higher prices for the palm fruit as compared to SMEs of the palm oil producing sector in the district. In addition, the sector is faced with inadequate facilities needed for production. This capital inadequacy prevents them from expanding and even some are on the verge of collapsing.

In the light of these problems, the study tried to find out sources of funds available to the palm oil producing sector in the Ahanta West District in the Western Region of Ghana and find means that will help them increase production and minimise the above mentioned constraints faced by these oil palm producers in the district.

\subsection{Objective of the Study}

Specifically the objectives of this study were to:

a) Identify the various sources of funds available to the SMEs in the oil palm producing sector of the Ahanta West District of the Western Region.

b) Find out whether funds have been actually accessed by oil palm producers.

c) Find out whether proper records are kept by the oil palm producers to attract investors.

\section{Literature Review}

\subsection{Characteristics of SMEs}

Due to the importance of small businesses to the development and growth of economy, the World Bank initiated a project, with the aim to develop and strengthen on a sustainable basis, the capacity of local intermediaries to deliver financial and non-financial services to SMEs and ensure that SMEs make productive use of these services. The importance of SMEs to employment in an economy cannot be over emphasised. According to Small Business Services(SBS), SMEs in the UK have an annual turnover of \$1 trillion and employed 12 million people in the UK between 1995 and 1999.

When businesses were springing up or showing signs of growth, business owners were deceived into thinking that all was well only to find out during an economic downturn that the business was really shallow and then eventually collapsed. The study of SBS showed that generally $95 \%$ of the SMEs folded up before their 5th year (SBS, 2002).SBS had on record that $92 \%$ and $66 \%$ of SMEs formed in 1995 and 1999 survived for 12 months and 3 years respectively.

a) Most SMEs in Ghana close down their businesses after only five years of operation. According to Arthur(2009) Ghanaian SMEs have the following characteristics: Lack of financial support from government or government agencies;

b) Businesses are usually family-owned and run by the family with few or no outsiders;

c) SMEs are owner-managed;

d) No formal strategy or plan to run the business (that is, their strategies are implicit). 
e) Employ few semi-skilled personnel between 1 and 50 .

f) They operate from low-cost premises.

g) They are flexible in their management style, usually considered as a competitive threat to existing large firms.

The World Bank's Country Director for Ghana, Mats Karlsson, when launching a project for SMEs in Ghana said: "Growth and employment in Ghana were directly linked to the growth of SMEs. It was important to state here that financial management function in a small enterprise ought to be seen as paramount.According to Fisher and Reuber, (2000), they enumerated a number of characteristics of SMEs in developing countries under the broad headings: labour characteristics, sectors of activity, gender of owner and efficiency. Given that most SMEs were one-person businesses, the largest employment category was working proprietors. This group makes up more than half the SME workforce in most developing countries; their families, who tend to be unpaid but active in the enterprise, make up roughly another quarter. The remaining portion of the workforce was splitted between hired workers and trainees or apprentices. SMEs are more labour intensive than larger firms and therefore have lower capital costs associated with job creation (Anheier\& Seibel, 1987;Liedholm\& Mead, 1987; Schmitz, 1995).

According to Fisher and Reuber, (2000), SMEs are mostly engaged in retailing, trading, or manufacturing. While it was a common perception that the majority of SMEs will fall into the first category, the proportion of SME activity that takes place in the retail sector varied considerably between countries, and between rural and urban regions within countries. Retailing SMEs were mostly found in urban regions, while manufacturing can be found in either rural or urban centres. However, the extent of involvement of a country in manufacturing will depend on a number of factors, including, availability of raw materials, taste and consumption patterns of domestic consumers, and the level of development of the export markets.

\subsection{Characteristics of SMES in Ghana}

In Ghana, $80 \%$ of businesses fall within the category of Micro, Small and Medium Enterprises (MSME)and with an employment capacity of close to $70 \%$ of the Ghanaian labour force. They range from farming activities, agri-businesses, light manufacturing, art and craft (usually referred to as cottage industries), textiles and garments (also known as tie and dye), tourism, financial services, construction and carpentry.

In Ghana, SMEs can be categorized into urban and rural enterprises. The former can be subdivided into "organized" and "unorganized" enterprises. The organized ones mostly have paid employees with a registered office, whereas the unorganized category of SMEs are made up of artisans who work in open spaces, temporary wooden structures, or at home, and employ few or in some cases no salaried workers. The unorganized enterprises rely mostly on family members or apprentices. Rural enterprises are largely made up of family groups, individual artisans, women engaged in food production from local crops. The major activities within this sector include soap and detergents, fabrics, clothing and tailoring, textile and leather, village 
blacksmiths, tin-smiting, ceramics, timber and mining, bricks and cement, beverages, food processing, bakeries, wood furniture, electronic assembly, agro processing, chemical-based products and mechanics (Osei et al., 1993; Kayanula\&Quartey, 2000).

Majority of SMEs are female-owned businesses, which more often than not are home-based as compared to those owned by males. They operate from home and are mostly not considered in official statistics. This clearly affected their chances of gaining access to financing schemes, since such programmes are designed without sufficient consideration of the needs of businesses owned by females. These female entrepreneurs often get the impression that they are not capable of taking advantage of these credit schemes, because the administrative costs associated with the schemes often outweigh the benefits.

Empirical studies in Ghana have shown that female-owned SMEs often have difficulty accessing finance. Females are mostly involved in sole-proprietorship businesses which are mainly microenterprises and as such may lack the necessary collateral to qualify for loans (Abor \&Biekpe, 2006). Measures of enterprise efficiency (e.g. labour productivity or total factor productivity) vary greatly both within and across industries. Firm size may be associated with some other factors that are positively correlated with efficiency, such as managerial skill and technology, and the effects of the policy environment. Most studies in developing countries indicate that the smaller firms are the least efficient, and there are some evidence that both small and large firms are relatively inefficient compared to medium-scale enterprises (Little et al., 1987). It is often argued that SMEs are more innovative than larger firms. Many small firms bring innovations to the market place, but the contribution of innovations to productivity often takes time, and larger firms may have more resources to adopt and implement them (Acs et al., 1999).

\subsection{Finance available to Small and Medium Scale Enterprises}

There are various sources of finance for SMEs. According to Jiang, Li and Lin (2014) SMEs can be finance through internal and external means. Internal financing in fact means enterprises get capital internally, mainly from retained profits, which is an essential part for the survival and development of the enterprises. Generally speaking, internal financing is the first choice, an important source to get capital. External financing includes funds from other independent economical entities, including direct financing and indirect financing. Direct financing mainly involve bond financing, stock financing and public funds. Indirect financing includes bank loans and the funds from non-bank institutions. Compared with internal financing, external financing makes available funds in time, but at high cost.

According to Ewiwile, Azu and Owa (2011), sources of finance available to SMEs are:

a) The owner-savings and savings from owner's associates including family and friends who may or may not be partners or shareholders in the venture.

b) Partners and shareholders in the venture.

c) Banks and lending institutions.

d) The small business administration and financial assistance programme. 
e) Members of the trade, including suppliers of materials such as manufacturers and wholesalers, and in some instances, customers who prepay their contracts.

f) Other businesses, local capitalist sales finance companies, factor and other sources.

Owner- savings is the major source of finance for most SMEs. According to Titman and Wessels (1988), small firms use more short-term finance than their larger counterparts because smaller firms have higher transactions costs when they issue long-term debt or equity. They further added that such behaviour may cause a "small firm risk effect" by borrowing more short-term, these types of firms would be more sensitive to temporary economic downturns than larger firms. From the study of Yuan (2005), there is a relationship between interest rate and loan given to SMEs. As the interest rate reduces, more loans were given out and as the interest rate increases less loans were given. The type of interest rate chosen depends on the income generated by the SME.

With the diversification of capital markets, SMEs in debt have more design options, the most common choice was a fixed rate or floating interest rates. First, if the future cash flows compared to determine the project can take short-term then the floating rate would be applied. Secondly, if a more definite future projects can be long-term then fixed-rate is used in financing the loan.

According to Abor and Biekpe (2006), capital structure of a firm was the relative amount of debt and equity the firm uses to finance its operations. Capital structure decisions were crucial for the survival of any business organization. The key was for firms to choose a portfolio of capital structure that will maintain sustainability and generate more wealth. In general, a firm can choose among many alternative capital structures.

This subject matter was one of the most contentious issues if not a puzzle in finance. A number of these theories have attempted to explain the variation in debt ratios across firms. The theories suggest that firms select capital structure depending on attributes that determine the various costs and benefits associated with debt and equity financing. However, these theories have been developed to explain financing preferences focusing on large listed firms. The issue of whether these findings were valid for other firms, especially SMEs, has received limited attention. The issue was particularly important for SMEs who do not have access to public capital, yet make very significant contributions to the economic growth in most countries. Short-term debt constitutes a relatively high proportion of total debt of Ghanaian SMEs. This represent close to $40 \%$ of total financing of SMEs in Ghana. The determinants of SMEs' capital structure include age of the firm, size of the firm, asset structure, profitability, growth and risk.

\section{Methodology}

The study uses the descriptive method. This type of study enables one to understand the nature of the problem and obtain information concerning the status of the problem to describe what exists with respect to variables or conditions. The main goal of this type of study is to describe the data and characteristics about what is being studied. The idea behind was to study frequencies, averages, and other statistical calculations in relation to the financing of SMEs in 
the Oil Palm Producing Sector. This would help in collecting data for a definite purpose in testing the research questions of the study. Data was collected using questionnaire.

\subsection{Population}

Population is defined as the totality of people or items with the same characteristics. For this study, the population comprises all oil palm producers in the Ahanta West District of the Western Region of Ghana. The producers of the oil palm are normally within the various towns of the District and these wereAboadze with total producers of 30 respondents, Ewoseadwo having 70 respondents, Aiyiem with thirty six 36 respondents and Akatenkye having total of 45 respondents given a total population of 181 oil palm producers.

\subsection{Sample Size}

For better understanding and analysis of the study, based on the numerical strength of the towns, percentages were used to draw the sample size. Greater percentages were allocated to towns with much oil palm producers while smaller percentages were allocated to towns with less oil palm producers. 17\% was allocated to respondents in Aboadzerepresenting a sample size of 5 while $39 \%$ was allocated to Ewoseadwogiven a sample size of 27. Aiyiemwas allocated with $20 \%$ of respondents representing 7 respondents. Akatenkyi had a percentage of $25 \%$ representing 11 of the respondents. Total sample size of 50 respondents was chosen for the study.

\subsection{Sampling Technique}

The sampling techniques used were stratified, quota and purposive sampling technique. Stratified sampling technique was used to select the respondents based on the study area. Therefore, the four main strata were Aboadze, Ewoseadwo, Akatenkye and Aiyiem. Quota sampling technique is a type of non-probability sampling, which involve a specific number of respondents been selected from the population. For this study, various percentages were used to draw the sample size based on the numerical strength of the strata. Purposive sampling method is whereby the selection of the respondents is based on the judgment of the researcher, and that those selected are the key individuals who can give the information needed for the study. This method was also used in selecting respondents from the financial institution (Ahantaman Rural Bank). The officer in-charge of microfinance was purposively selected for the study.

\subsection{Data Collection}

Primary data and secondary sources of data were used to gather information for the study. The use of primary data enabled the study to identify the various sources of funds and problems encountered by oil palm producers in their operation to increase output through administered questionnaires to 50 respondents from the palm oil producers. Questionnaires involved bothopen and close-ended questions which was personally administered to respondents. Unstructured interviews were conducted for respondents from the financial institution, that is, the officer in charge of microfinance at Ahantaman Rural Bank. An unstructured interview was appropriate for the study because it was easier to obtain vital 


\section{Al Macrothink}

Business and Economic Research

ISSN 2162-4860

2016, Vol. 6, No. 1

information since some responses may not be part of the subject matter but led in gathering the right information for the study.

\subsection{Data Presentation and Analysis}

Both quantitative and qualitative approaches were used in analyzing the data. The quantitative approach enabled the statistical representation of the data to ease the understanding and interpretation. Data were gathered from the questionnaires administered and unstructured interview conducted. Excel was used in analyzing the data and quantitative tool such as tables and charts were used in presenting the results to enable a clear understanding of the variables used. Qualitative approach was used mainly to find out whether the study confirms or disagrees with the study of other researchers for which conclusions were drawn.

\section{Results and Discussion}

\subsection{Gender of Respondents}

Figure 1 below gives the gender distribution of the respondents.

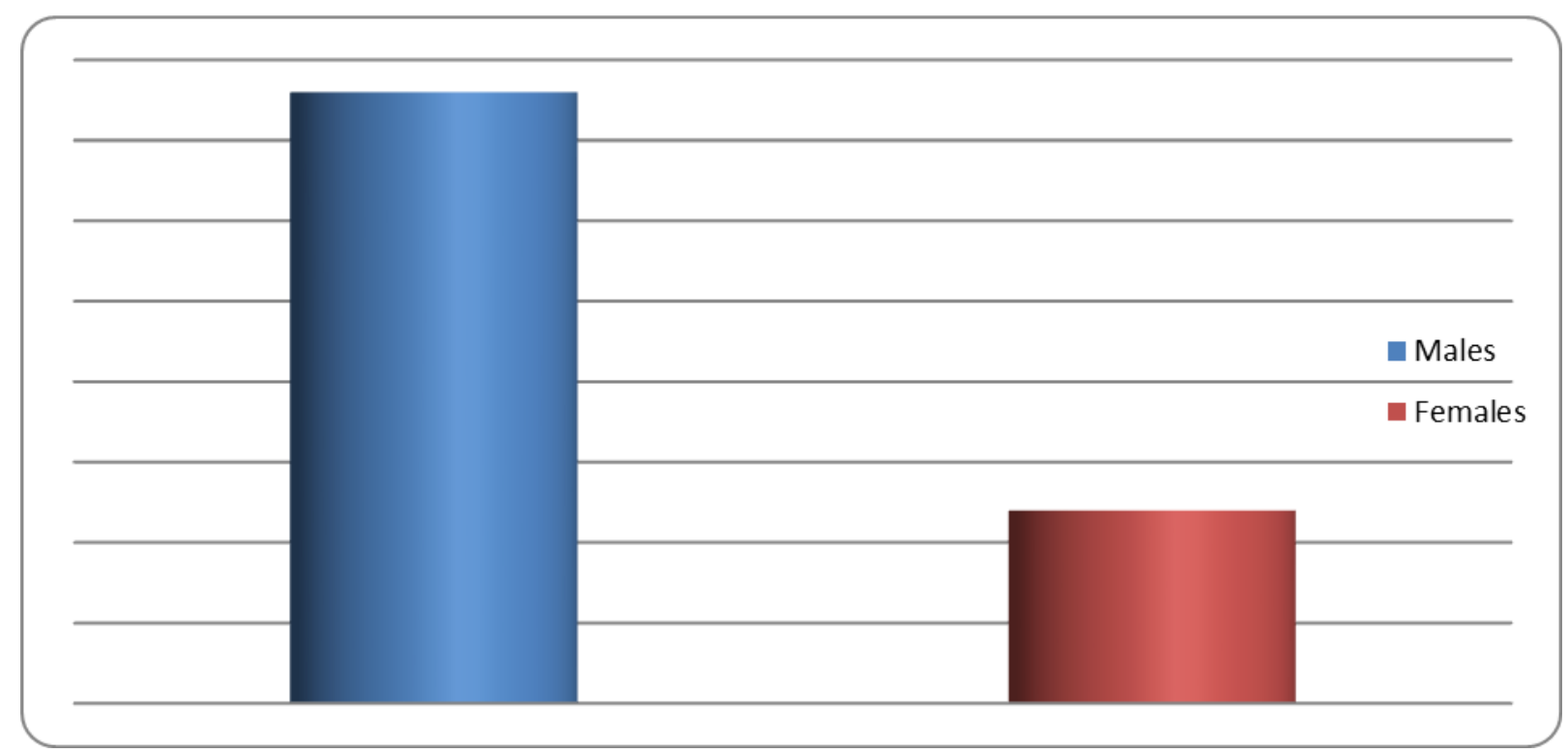

Figure 1. Gender distribution respondents

Source: Field Survey (2011)

From Figure 1, majority of the respondents were females (76\%) while the remaining respondents, (that is 24\%) were males. This confirms the study of Abor and Biekpe, (2006) stating that majority of SMEs were female-owned businesses, which more often than not were home-based compared to those owned by males operated from home and were mostly not considered in official statistics.

\subsection{Age of Respondents}

Table 1 below gives the age brackets of the respondents. 
Table 1. Age distribution of respondents

\begin{tabular}{|l|l|l|}
\hline Age range (years) & Frequency & Percentage (\%) \\
\hline $18-30$ & 8 & 16 \\
\hline $31-40$ & 25 & 50 \\
\hline $41-50$ & 12 & 24 \\
\hline Above 50 & 5 & 10 \\
\hline Total & 50 & 100 \\
\hline
\end{tabular}

Source: Field survey (2011)

From Table 1 above, it can be seen that majority of the respondents (50\%) fell within the age range of 31-40 years and these were the youth who were actively involved in oil palm production. This group has the energy of growing their businesses that leads to the growth of the economy as a whole and have the ability to better their standard of living as compared to $10 \%$ of the remaining respondents who were above 50 years. The group above 50 years have less strength to cause a an increase in production since of oil palm production demand much strength due to the use of manual way of producing oil palm.Also $24 \%$ and $16 \%$ of the remaining respondents fell within the age ranges of 41-50 years and 18-30 years respectively, which implied that this group (i.e. 18-30 years) are still schooling and are not actively involved in the business.

\subsection{Educational Background of Respondents}

Table 2 below presents the various educational levels attained by the respondents.

Table 2. Educational levels of respondents

\begin{tabular}{|l|l|l|}
\hline Educational levels & Frequency & Percentages (\%) \\
\hline Elementary school & 22 & 44 \\
\hline Junior high school & 10 & 20 \\
\hline Senior high school & 6 & 12 \\
\hline Tertiary & 4 & 8 \\
\hline No Formal education & 8 & 16 \\
\hline Total & 50 & 100 \\
\hline
\end{tabular}

Source: Field survey (2011)

From Table 2 above, majority of the respondents (44\%) had elementary education, whiles minority $(8 \%)$ of respondents had tertiary education. This implies that majority $(40 \%)$ of the respondents do not have a solid foundation in the formal education. This impedes the gathering of information regarding their business and goes a long of hindering the progress of their operation. Also only $20 \%$ of respondents had junior high school education as compared to $12 \%$ of the remaining respondents who had some secondary education.

\subsection{Years in business}




\section{Macrothink}

Business and Economic Research

ISSN 2162-4860

2016, Vol. 6, No. 1

Table 3 below shows the number of years the respondents have worked as oil palm producers

Table 3. Number of years in business

\begin{tabular}{|l|l|l|}
\hline Number of years & Frequency & Percentage (\%) \\
\hline $1-3$ & 3 & 6 \\
\hline $4-6$ & 7 & 14 \\
\hline $7-9$ & 18 & 36 \\
\hline 10 and above & 22 & 44 \\
\hline Total & 50 & 100 \\
\hline
\end{tabular}

Source: Field survey (2011)

Table 3shows that greater proportions of the respondents have been in business for over five years, and they stand a chance of attracting any investor. This agrees with the study of Myers, (1977) who stated that age of the firm was a standard measure of reputation in capital structure models. As firm ages, it establishes itself as a going concern and therefore increases its capacity to take on more debt; hence age was positively related to debt. Before granting a loan, banks tend to evaluate the creditworthiness of entrepreneurs.

\subsection{Readiness of Product}

The study sought to find out whether the oil palm has a ready market and the identification of the various customers of the product. All the 50 respondents representing $100 \%$ stated that the product has a ready market. This is shown in Figure 2 below. Some of their customers were the market women who purchased palm oil for resale, educational institutions for the preparation of food for students, soap manufacturers and others for export.

\subsection{Production at Full Capacity}

The study also identifies whether they produced at full capacity and if not, espouse the reasons for not producing at full capacity. This is shown in figure 2 below:

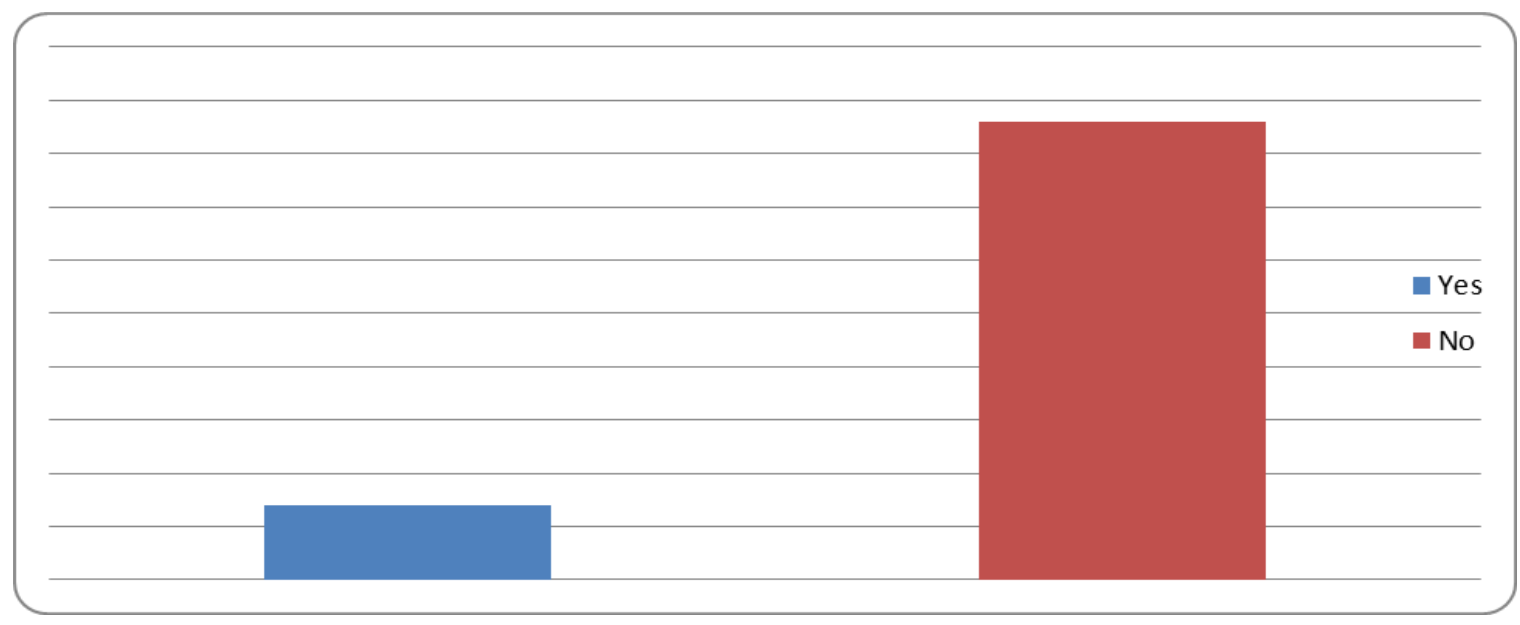

Figure 2. Production at full capacity

Source: Field Survey (2011) 
From figure 2 above, majority (83\%) ofrespondents answered 'No' meaning that they do not produce at full capacity as compared to minority (17\%) of respondents who stated that they produce at full capacity. This means that majority of respondents representing $83 \%$ do not produced to full capacity and when asked why not producing at full capacity, the reason they gave was that, there was not enough funds to purchase palm fruits which prevents them from producing to meet the actual demand of the market, that is, demand always exceeds supply.

\subsection{Number of Employees}

Table 4 shows the number of workers employed in the production of palm oil.

Table 4. The number of workers employed

\begin{tabular}{|l|l|l|}
\hline Number of workers & Frequency & Percentages (\%) \\
\hline $3-5$ & 43 & 86 \\
\hline $6-8$ & 7 & 14 \\
\hline $9-12$ & 0 & 0 \\
\hline Above 12 & 0 & 0 \\
\hline Total & 50 & 100 \\
\hline
\end{tabular}

Source: Field survey (2011)

Table 4 shows that majority of the oil palm producers employ less than 6 workers. When asked why not employing more hands to help in the production of palm oil, all respondents attributed the situation to lack of funds which prevented them to employ more workers to increase production as well as contribute to reducing the unemployment rate in the Ahanta West District Assembly and the country at large. This is in line with the definition of SMEs in terms of number of employees for developing countries given by UNIDO stating thatlarge firms employ 100 or more workers; medium firms employ 20-99 workers; small firms employ 5-19 workers; micro - firms has less than 5 workers (Elaian, 1996). It can be deduced that greater portion of the respondents employed $3-5$ workers.

To further find out from respondents whether workers employed to work were solely family members or not, majority ( $92 \%$ ) of respondents confirmed that all workers employed were indeed family members while the remaining respondents $(8 \%)$ indicated that they employed people other than family members to help them in the production of oil palm. This means that majority of the respondents worked with their family members mainly husband, wife, some of the children who were interested in the oil palm production. This confirms the study of Osei et al., (1993) ; Kayanula and Quartey, (2000) which states that " rural enterprises are largely made up of family groups, individual artisans, women engaged in food production from local crops. The major activities within this sector include:- soap and detergents, fabrics, clothing and tailoring, textile and leather, village blacksmiths, tin-smiting, ceramics, timber and mining, bricks and cement, beverages, food processing, bakeries, wood furniture, electronic assembly, agro processing, chemical-based products and mechanics."

The study further assessed whether respondents would be in the position to employ more workers which all the respondents $(100 \%)$ indicated that more people will be employed if 


\section{Macrothink}

they are to produce at full capacity. This means that having funds available will go a long way to increase production and consequently increase the employment rate in the Ahanta West District and the country as a whole.

\subsection{Plant and Machinery Used In Production}

The study sought to identify the ownership of plant and machinery used in the production of the oil palm with results illustrated in Figure 3 below.

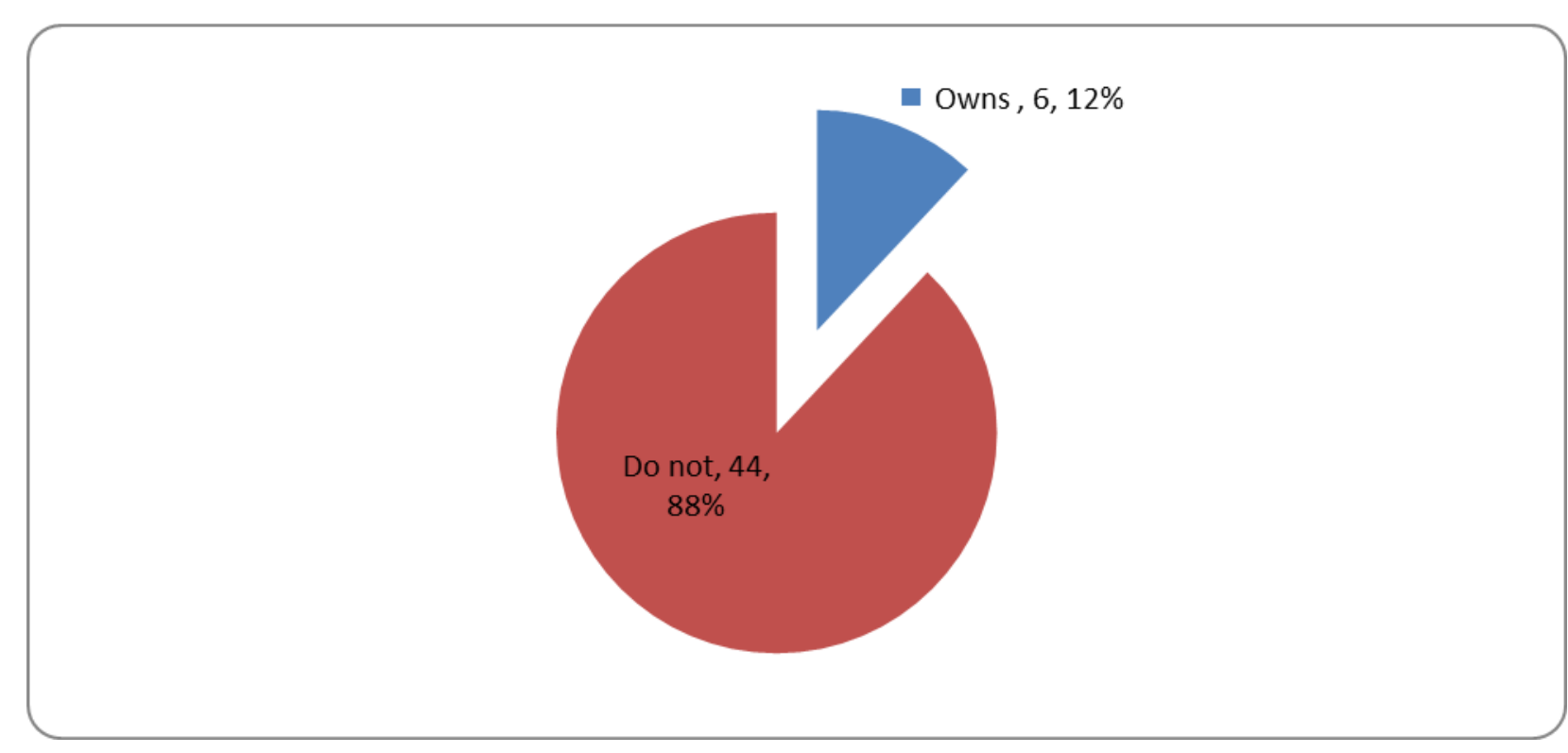

Figure 3. Ownership of plant and machines used in production

Source: Field survey (2011)

From the Figure 3 below, majority of respondents (88\%) do not own the plant and or machines used in producing oil palm but depended on other people's machines for the production of palm oil as compared to only $12 \%$ of remaining respondents who owned their own plant and machinery. Unfortunately, those who own machines for oil palm production were not into oil palm production themselves but were being set-up for hiring to generate income from the oil palm producers. This implied that majority $88 \%)$ depended on others for production also drains some of the funds at hand, which could otherwise be used to purchase raw materials to increase production. Also, without personally owned plant and machinery, the possibility of borrowing from banks may not be realized since some banks rely on these assets as collateral.

According to Bradley et al., (1984), firms that invest heavily in tangible assets tend to have higher financial leverage since they borrow at lower interest rates if their debt was secured with such assets. It was believed that, debt may be more readily used if there were durable assets to serve as collateral (Wedig et al., 1988) while high transaction costs, risks related to small loans, and lack of collateral restricted SMEs access to formal credit (Steel, 1994). 


\section{Macrothink}

Business and Economic Research

ISSN 2162-4860 2016, Vol. 6, No. 1

The study identified the various sources of funds of the palm oil businessas personal savings, borrowing from moneylenders, borrowing from family members or purchasing of input from suppliers on credit. This is shown in figure 4 below.

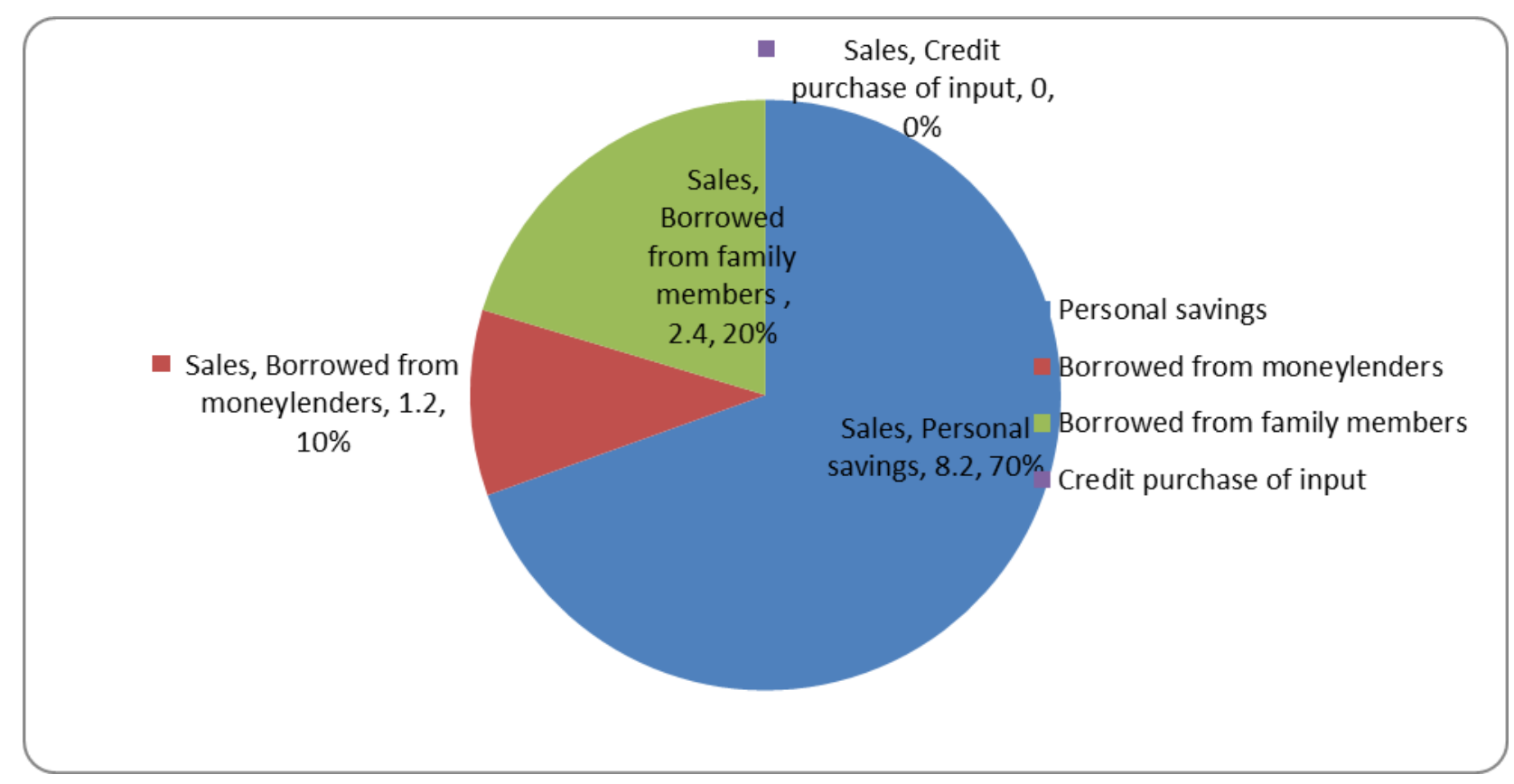

Figure 4. Sources of Funding

Source: Field Survey, 2011

From figure 4, majority $(70 \%)$ of respondents of the oil palm producers finance their business through personal savings, $20 \%$ of the respondents indicated that the source their funds from family members and $10 \%$ of remaining respondents stated that they finance their business through borrowing from moneylenders. This was because majority of producers were not enlightened on how they can expand their business using other sources of fund. In addition, they wereafraid of not being able to pay back the borrowed funds.

\subsection{Accessing Loans from Banks}

The respondents were asked if they are able to source for fund from banks. Their responses are shown in figure 5 below: 


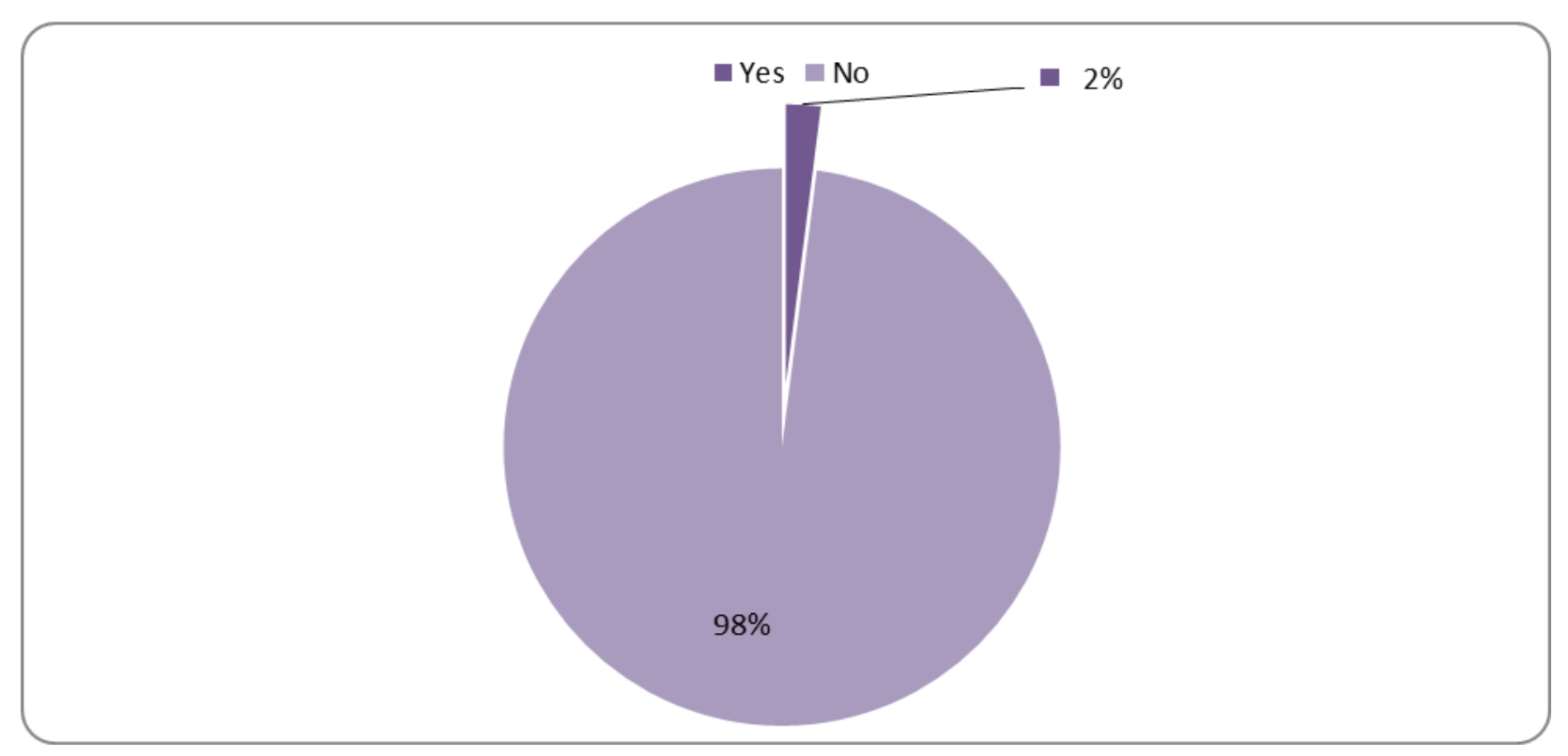

Figure 5. Accessing Loan from banks

Source: Field Survey, (2011)

From the Figure 5 below, majority (98\%) of the respondents answered 'No' meaning that they have not had the opportunity of receiving any loan from any bank. Among the reasons respondents gave for not having the opportunity of accessing loans from banks was that they were afraid of not being able to pay back. In addition,the banks denied thosewho attempted to secure bank loans. Minority (2\%) has made use of the loan facility. Before the loan was granted, a specific amount had to be deposited as collateral or one has to find a guarantor.

\subsection{Purpose of Existence of the bank}

From the interview conducted, the study revealed that banks were established to help the people in the various localities to serve and provide them with needed funds to run their businesses in order to improve their living standards. Also in order to be socially responsible, the bank offered scholarships to needy but brilliant students in the Ahanta West District an well as carry developmental projects in the respective localities. In order to make sure that needed funds were well disbursed and results thereof evaluated microfinance section was created by the bank (Ahantaman Rural Bank) to provide such services.

This confirms the study of Leila, (2006) that microfinance in Africa had developed in different stages across the region. Financial intermediaries such as cooperatives, rural and postal savings banks pioneered the industry in the 1970s, especially in West and East Africa. The findings are also in agreement with the study of Johnson \&Rogaly (1997) that, in the 1990s, microfinance schemes were established to provide financial services in the form of savings and credit opportunities to the working poor.

\subsection{Provision of Loans to SMEs}

The study revealed that the bank (Ahantaman Rural Bank) provided loans to all forms of 


\section{Ml Macrothink}

SMEs in the locality. Some of which were agro-farmers, traders, drivers, etc. which the oil palm producers are of no exception. The bank required that the SME owners to saved with the bank and provided two guarantors before loan was granted with no collateral demanded. It was revealed by the bank that no ceiling was placed on the loan facility provided the client had an amount in his/her account.This was in agreement with the study of Gert van (2004) who explained microfinance as banking for the unbankables, bringing credit, savings and other essential financial services within the reach of millions of people who were too poor to be served by regular banks, in most cases because they were unable to offer sufficient collateral for the acquisition of loan from bank.

\subsection{Payment of Loans by SMEs}

The study also identified that most SMEs failed to pay back the loans granted them by respective financial institutions because some of them fail to use the loan for the intended purpose. Although monitoring systems were in place to monitor its intended purpose, there was misapplication of the said funds. Those who utilized the loan wisely experienced improvement in their production, which goes a long way of bettering the living standard of the people as well as fulfilling the purpose for which the microfinance was established. This agrees with Gert van (2004), microcredit played an important role in fighting the multi-dimensional aspects of poverty. Microfinance increases household income, which leads to attendant benefits such as increased food security, the building of assets, and an increased likelihood of educating one's children as well as a means for self-empowerment. It enables the poor to make changes when they increase income, become business owners and reduce their vulnerability to external shocks like illness, weather and more.

\subsection{Investment of Profit}

The study finds out whether the profit earned isinvested in the business. This is illustrated in the figure 6 below.

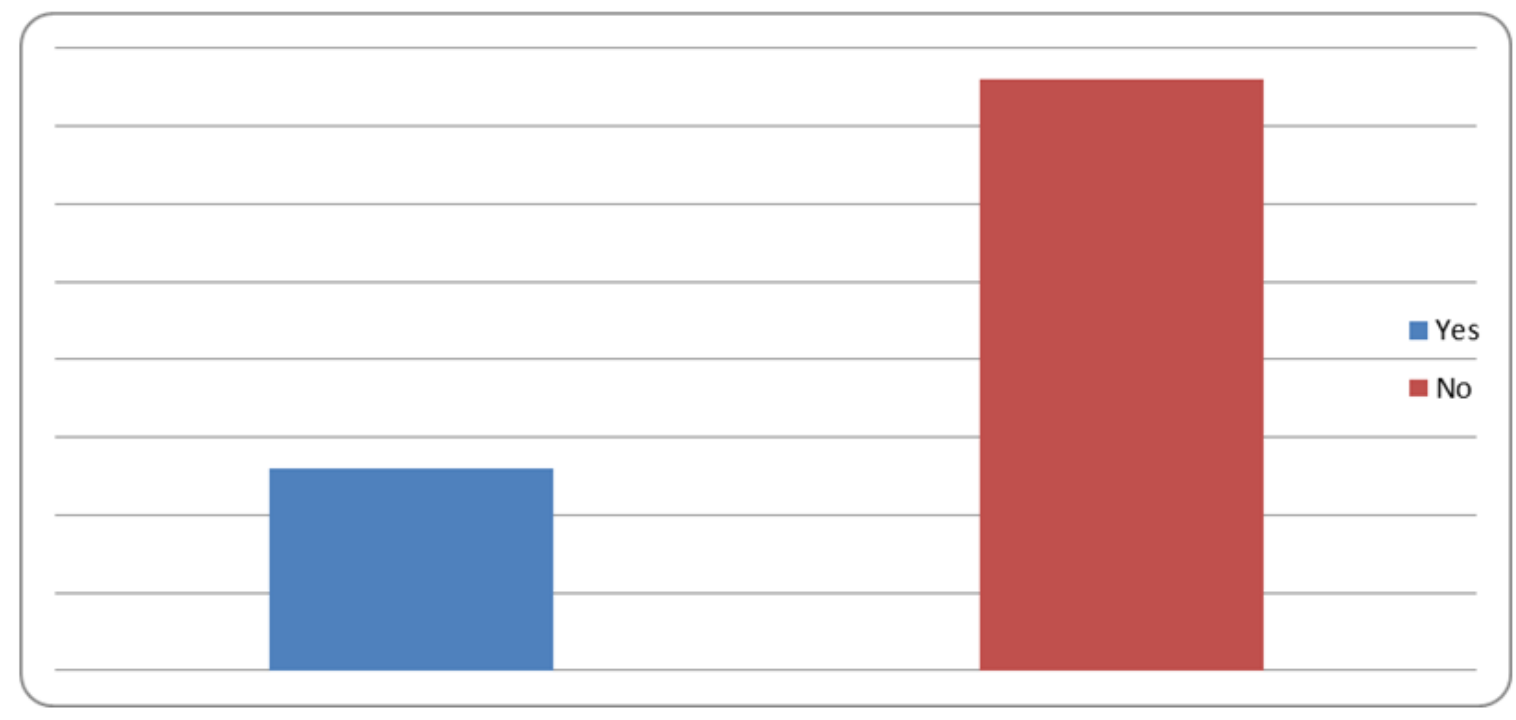

Figure 6. Investment of profit 
From figure 6, majority (74\%) of the respondents said 'No' meaning that they do not invest their profit in the business but rather depend on it for survival. By so doing, it impedes growth of the business since there were no other available means of financing the business. On the other hand, minority $(26 \%)$ of the respondents did confirm they invest their profits back into the business to increase their production as well as expend the business. This finding does not support the study of Titman and Wessels, (1988) and Barton et al, (1989) who argued that, profitable firms, which have access to retained profits, can rely on it expansion as opposed to depending on outside sources (debt).

\subsection{Funds from Non-government Organisations (NGO's)}

Apart from the usual financial institution, the study tried to find out if any NGO has come in to fund the production of oil palm. All respondents (100\%) have not had any NGO helping with funding of oil palm production. This means that these oil palm producers in the Ahanta West District of the Western have been deprived of financial support from government and other NGO's.

\subsection{Record Keeping}

The importance of record keeping cannot be underemphasized. All the respondents $(100 \%)$ do not keep records of their business transaction. This explains why the traditional commercial banks are reluctant to give the palm oil producers credit. This confirms the assertion by theUnited Nations Conference on Trade and Development (UNCTAD) conference report in 2000 that traditional commercial banks and investors had been reluctant to service SMEs because of information asymmetry arising from SMEs' lack of accounting records, inadequate financial statements or business plans. This makes it difficult for creditors and investors to assess the creditworthiness of potential SME proposals for funding.

\section{Conclusion}

From the study majority of respondents depend on their personal saving as their major source of funding for the palm oil production. Also, because of funding problem, most palm oil producers do not personally own plant and machinery used in the palm oil production.It was also evident that the palm oil producers stand a little chance of accessing bank loansbecause they are unable to prepare dossiers which can be used as a means to assess their business performance.They are also afraid of not being able to pay case of difficulty and been denied of access of loan by Microfinance institutions, even though they made the attempt of accessing the loan facility. In addition, majority of oil palm producers do not have access to raw material (that is palm fruit) therefore leading to low production. It was revealed that, majority of the palm fruit producers preferred selling to Norpalm Limited and Benso Oil Palm Limited because these companies offered higher prices than local producers.

It can be said that majority of respondents do not invest their profits but rather depend on it for survival. By so doing, it impedes growth of the business since there are no other available means of financing the business. The importance of record keeping cannot be left out in this important study therefore, from the interviewed conducted and questionnaire administered, all the respondents do not keep recordings regarding their operation because they do not see 
the importance of records keeping and were mostly of low educational background or no formal education.

It is worth noting that the private sector is the engine of growth. Because of this the government and other stakeholder should take interest in the development of SMEs in order to propel the required growth. Special training programmes can be organized for SMEs owners on business and financial management. They can also be linked to institution such as the Council for Technical and Vocational Educational and Training (COTVET) by the Government of Ghana to help champion and guide them in running their businesses and also to provide them with financial assistance.

\section{References}

Abor, J., \& Quartey, P. (2010). Issues in SME Development in Ghana and South Africa. International Research Journal of Finance \& Economics/14502887, 20100501.

Abor, J., \& Biekpe, N. (2006). SMEs' Access to debt finance: A comparison of male-owned and female-owned businesses in Ghana. International Journal of Entrepreneurship and Innovation, 7(2), 105-112. http://dx.doi.org/10.5367/000000006776928627

Acs, Z., Morck, R., \& Young, B. (1999). Productivity growth and size distribution. In Acs, Z., Carlsson, B. \& Karlsson, C. (eds.), Entrepreneurship, small and medium-sized enterprises and the macroeconomy. Cambridge: Cambridge University Press.

Afrane, S., (2002).Impact assessment of microfinance interventions in Ghana and South Africa. Journal of Microfinance, 4(1), 37-58.

Aggarwa, S. Klapper, L., \& Singer, D. (2012). Financing businesses in Africa: The role of microfinance. World Bank Policy Research Working Paper 5975.

Afrane, S. (2000). Impact Assessment of Microfinance Interventions in Ghana and South Africa:A report preparedfor Sinapi Aba Trust - A Micro-Financing Agency in Ghana and Soweto Microenterprise DevelopmentProject (SOMED), South Africa.

Aryeetey, E. (1998). Informal finance for private sector development in Africa.Economic Research Papers No. 41. Abidjan: The African Development Bank.

Asmamaw Y. C. (2014). The Role of Microfinance Institutions in the Development of Small and Medium Size Businesses in Ethiopia, A Case Study in Amhara Credit and Saving Institutions. International Research Journal of Finance and Accounting ISSN 2222-1697 (Paper) ISSN 2222-2847 Vol.5, No.13, 2014

Associaation of Chartered Certified Accountant (2008).Financial Management (2nd ed.). London: BPP Learning Media Limited.

Bennett, R. (1998). Small business survival:Strategies for delivering growth and staying profitable (2nd ed). London: Financial Times.

Beck, T., \& Demirguc-Kunt, A., (2006).Small and medium-size enterprises: Access to finance as a growth constraint, Journal of Economic Growth, Paper 18-19. 


\section{Macrothink}

Business and Economic Research ISSN 2162-4860 2016, Vol. 6, No. 1

Bolton, J. E. (1971). Report of the Committee of Inquiry on Small Firms. London: HMSO.

Elaian, K., (1996). Employment implications of small scale industries in developing countries: Evidence from Jordan. International Research Journal of Finance and Economics, 39(2010), 227

Ewiwile, S. Azu, B., \& Owa, F. (2011). Effective financing and management of small scale businesses in delta state, Nigeria: a tool for sustainable economic growth International Journal of Economic Development Research and Investment Vol 2 No. 3, Dec. 2011

Eric O. O., \& Kerongo (2014). The Effects of International Financial Reporting Standards Adoption on Smes Performance: A Case Study Mombasa - Central Business District (CBD). International Research Journal of Finance and Accounting ISSN 2222-1697 (Paper) ISSN 2222-2847 Vol.5, No.7, 2014

Fisher, E., \& Reuber, R. (2000).Industrial clusters and SME promotion in Developing Countries. Commonwealth Trade and Enterprise Paper No. 3. http://dx.doi.org/10.14217/9781848597266-en

Gockel, A., G., \& Akoena, S., K., (2002). Financial intermediation for the poor: Credit demand by micro, small and medium scale enterprises in Ghana: A Further Assignment for FinancialSector Policy?, IFLIP Research Paper 02-6, International LabourOrganisation.

Jiang, J. J., Li, Z. M. \& Lin, C. Y. (2014). Financing difficulties of smes from its financing sources in China.Journal of Service Science and Management, 7, 196-200. http://dx.doi.org/10.4236/jssm.2014.73016

Leila, M. (2009). Microfinance scaling-up in Africa: Challenges ahead and way forward. http://www.afdb.org/fileadmin/uploads/afdb/Documents/Generic documents/Concept\%20Note\%20Microfinance-\%20scaling\%20up\%20in\%20africa.pdf

Reindolf Y. N. A. Edem \& Maxwell A. (2014). Assessment of Supply-Side Financing of Lower-End Market SMEs by Rural Banks in Ghana. International Research Journal Of Finance And Accounting (Paper) ISSN 2222-2847 Vol.5, No.18, 2014

Yuan, F. (2005). Mid-level financial management. Shanghai: Fudan University Press

\section{Copyright Disclaimer}

Copyright for this article is retained by the author(s), with first publication rights granted to the journal.

This is an open-access article distributed under the terms and conditions of the Creative Commons Attribution license (http://creativecommons.org/licenses/by/3.0/). 